\title{
Identification of bacterial contaminants in polyherbal medicines used for the treatment of tuberculosis in Amatole District of the Eastern Cape Province, South Africa, using rapid $16 \mathrm{~S}$ rRNA technique
}

\author{
Elizabeth Bosede Famewo, Anna Maria Clarke and Anthony Jide Afolayan*
}

\begin{abstract}
Background: Polyherbal medicines are used for the treatment of many diseases in many African and Asian communities. With the increasing use of these remedies, several investigations have shown that they are associated with a broad variety of residues and contaminants. This study investigates the presence of bacteria in the polyherbal medicines used for the treatment of tuberculosis (TB) in the Eastern Cape Province of South Africa.

Methods: Bacterial DNA was extracted from the polyherbal medicines, and a fragment of the bacterial 165 rRNA gene was amplified by PCR with universal primers 27F and 518R. The amplicons were visualised on agarose gel electrophoresis, followed by end repair and adaptor ligation. They were further purified and quantified using Library Preparation kit NEBNext ${ }^{\oplus}$ UltraT DNA Library Prep Kit for Illumina, and the amplicons were run on illumina's MiSeq platform.

Results: Different bacterial species were identified in all each of the polyherbal medicines. Generally, the most prominent and common bacteria recovered from all the samples were Bacillus sp., Enterobacter sp., Klebsiella sp., Rahnella sp., Paenibacillus sp., Clostridium sp. and Pantoea sp. Others are Pseudomonas sp., Raoultella ornithinolytica, Salmonella enterica and Eubacterium moniliforme.

Conclusions: This study, thus, revealed the presence of pathogenic and non-pathogenic bacteria in the polyherbal medicines used for the treatment of tuberculosis in the study area. The implications of the findings are discussed in relation to the health care of the patients of tuberculosis in the study area, having in mind that they are immunocompromised individuals.
\end{abstract}

Keywords: Polyherbal medicines, Tuberculosis, Bacteria, Public health, Sequencing

\section{Background}

Polyherbal medicines have been used for various therapeutic purposes as far back as the origin of mankind. In South Africa, it is estimated that three million people currently use herbal remedies (polyherbal medicines) for their health care purposes especially in the treatment of diarrhoea, diabetes, stomach illnesses, wound infections and tuberculosis [1-3].

* Correspondence: aafolayan@ufh.ac.za

Faculty of Science and Agriculture, University of Fort Hare, Alice 5700, South Africa
About $1 \%$ of the South Africa population is estimated to develop tuberculosis yearly [4]. The country accounts for one quarter of the global burden of HIV-associated tuberculosis (TB) [5]. This is stimulated by the high rates of latent tuberculosis infection and the increase in the prevailing rates of infection [4]. In fact, about $50 \%$ of people among the age group 15 and $77-89 \%$ of adults have evidence of latent TB infection [6,7]. The use of the current drug regimen combinations for TB is limited due to patients' non-compliance, which has resulted in the rise of strains that are resistant to some 
or the entire first and second-line antibiotics [8]. The emergence of multi-drug resistant tuberculosis (MDRTB), extensively drug resistant tuberculosis (XDRTB), and totally drug resistant tuberculosis (TDR) has exacerbated the global health problem $[9,10]$. Due to the high resistance of $M$. tuberculosis to commonly prescribed antimicrobials, relatively high cost and limited access to synthetically derived drugs, most communities especially in Africa still rely on the use of polyherbal medicine for the treatment of their ailments [11, 12]. Yet, these medicines have been reported to contain a number of microbial and heavy metal contaminants [13-16].

Medicinal herbs frequently harbour a large number of microbes originating from the soil, and these microorganisms normally adhered to leaves, stems, flowers, seeds and roots of plants [17]. The contamination of herbal products with Enterobacteriaceae, Bacillus spp., Salmonella spp., Staphylococcus aureus, Penicillium spp. and Aspergillus spp. have been reported by [18]. Also, elevated levels of bacterial and fungal contaminants, such as Escherichia coli, yeast, Penicillium spp., Aspergillus and Fusarium, were observed in herbs and spices by $[14,19,20]$. The presence of these contaminants in the herbal products might adversely affect the health status of the consumers due to their immunocompromised conditions. Microbial infections have posed a health problem throughout the world, thus, the safety of the consumers of herbal products is of utmost importance.

To the best of our knowledge, the microorganisms present in some of the polyherbal medicines used for the treatment of TB in Amathole District Municipality of the Eastern Cape Province have not been investigated despite the mass consumption of the medicines. Most of these polyherbal remedies are prepared in the form of concoctions or infusions and are left at room temperature over a long period of time depending on how rapid the patients respond to treatment. During this period, the mineral elements present in these remedies may facilitate the growth of microorganisms. Thus, this study therefore aimed at identifying different bacteria present in some of the polyherbal medicines used for treatment of $\mathrm{TB}$ in the study area using molecular based technique.

\section{Methods}

\section{Sample collection}

A total of nine polyherbal medicines used for the treatment of TB were purchased from the traditional herbal sellers in five communities, namely East London (EL), King Williams Town (KWT), Hogsback (HB), Alice (AL) and Fort Beaufort (FB) as shown in Fig. 1. Each remedy was labelled and coded according to the place of collection, viz: King Williams Town site A (KWTa), King Williams Town site B (KWTb), King Williams Town site
C (KWTc), Hogsback first site (HBfs), Hogsback second site (HBss), Hogsback third site (HBts), East London (EL), Alice (AL) and Fort Beaufort (FB). The small number of remedies obtained in this study was due to the fact that only a few traditional healers treat and sell the remedies for TB. They claim to have acquired the knowledge from their ancestors, and this knowledge is been transferred from one generation to another. The samples were then transported to Medicinal Plants and Economic Development (MPED) Research Centre for analysis.

\section{DNA extraction}

The total bacterial DNA was extracted in a clean and sterilized environment using ZR Fungal/Bacterial MiniPrep $^{\text {Ts }}$ Kit (Zymo Research, USA). The method of [21] with slight modification was used for the extraction. One millilitre of each sample was pipetted into sterile eppendorff tubes and centrifuged at $12,500 \mathrm{rpm}$ for $10 \mathrm{~min}$. The supernatant was discarded, and the cell pellets were collected. The protocol in the extraction kit was followed.

\section{PCR amplification of bacterial DNA}

Polymerase chain reaction (PCR) was performed using the extracted DNA from each of the samples. The bacterial 16S rRNAs were amplified using the oligonucleotide primers 27F (5'-GGT AGA GTT TGA TCC TGG CTC AG-3') and 518R (5'-ATT ACC GCG GCT GCT GG-3'). The $16 \mathrm{~S}$ rRNA gene contains nine variable regions (designated V1 to V9) of which we chose the V1-V3 regions, which has previously proven useful in research-oriented metagenomic surveys [22]. A total reaction volume of $25 \mu \mathrm{L}$ was used, which contained $12.5 \mu \mathrm{L}$ Master Mix (Thermo Scientific, EU Lithuania), $1 \mu \mathrm{L}$ each of $10 \mu \mathrm{M}$ of both forward and reverse primer solutions (Inqaba Biotech, SA), $5.5 \mu \mathrm{L}$ of nuclease free water and $5 \mu \mathrm{L}$ template DNA. Reactions was performed in the thermocycler (Bio-Rad Mycycler, USA) using the following cycling conditions: initial denaturation at $94{ }^{\circ} \mathrm{C}$ for $1 \mathrm{~min}$, followed by 30 cycles of denaturation at $94{ }^{\circ} \mathrm{C}$ for $1 \mathrm{~min}$, annealing at $58^{\circ} \mathrm{C}$ for $1 \mathrm{~min}$, extension at $72{ }^{\circ} \mathrm{C}$ for $1.5 \mathrm{~min}$ and final extension at $72{ }^{\circ} \mathrm{C}$ for $10 \mathrm{~min}$ [23]. In order to confirm the products size, $5 \mu \mathrm{L}$ of the amplicons was analysed by gel electrophoresis in $1 \%$ agarose (Merck, SA) stained with $3 \mu \mathrm{L}$ ethidium bromide (Sigma-Aldrich, USA). A 100 bp DNA ladder for $16 \mathrm{~S}$ rRNA (Thermo Scientific, (EU) Lithuania) was included for band size estimation purposes. All gels were run in $0.5 \mathrm{X}$ TBE buffer at $95 \mathrm{~V}$ for $1 \mathrm{~h}$ and visualised by UV trans-illumination (Alliance 4.7, France).

Purification of 16S rRNA gene amplicons and sequencing The bacterial 16S rRNA gene amplicons were purified with the Zymoclean $^{\mathrm{Tm}}$ Gel DNA Recovery kit (ZymoResearch 


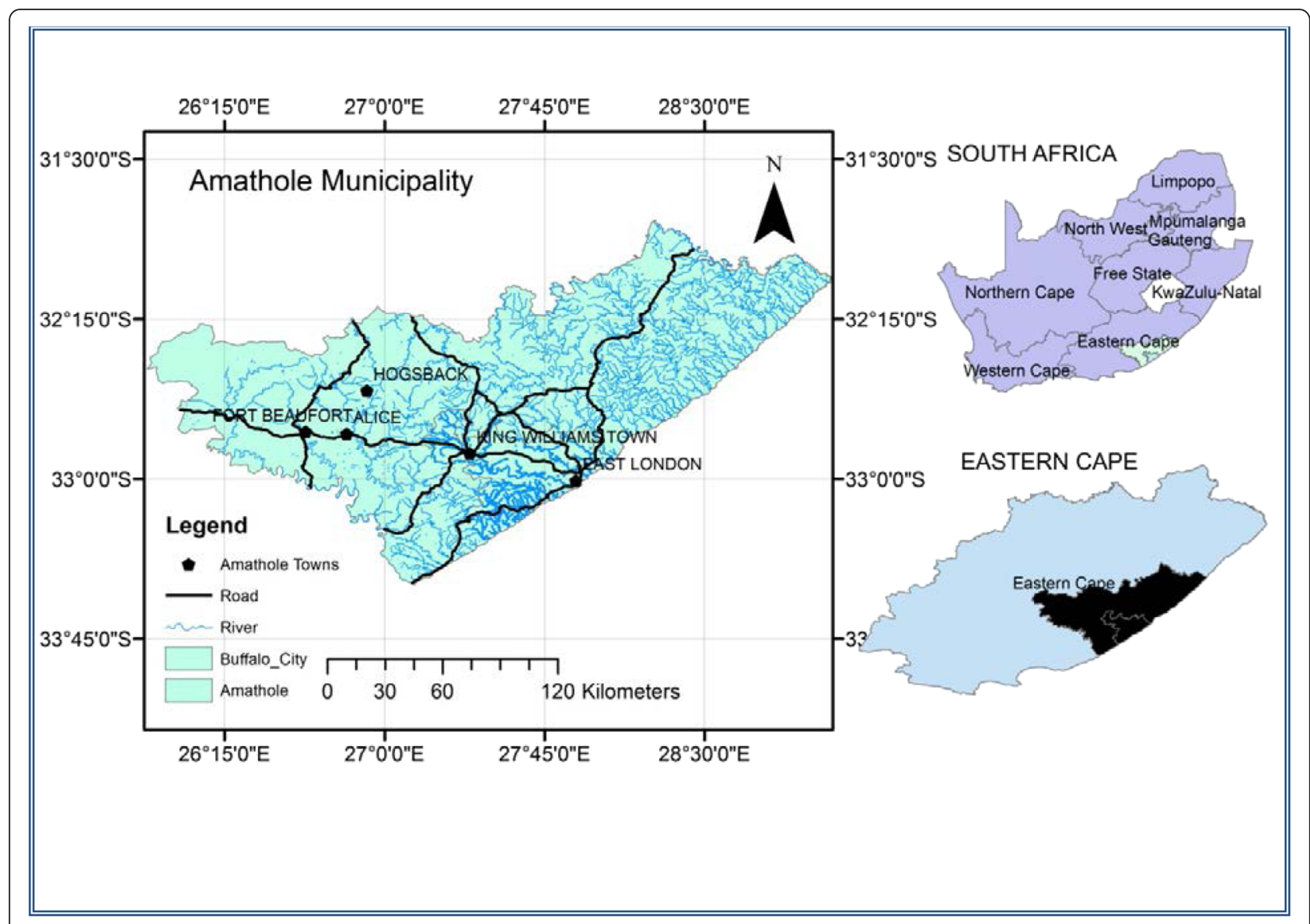

Fig. 1 Map of Amathole District Municipality

Corporation, Irvine, USA) and quantified using NanoDrop Fluorospectrometer ND3300 fragment size (Agilent Bioanalyzer 2100) prior sequencing. Followed by end repair and adaptor ligation and quantification of each library using Library Preparation kit $\left(\right.$ NEBNext $^{\ominus}$ UltraT DNA Library Prep Kit for Illumina), before running them on illumina's MiSeq platform following the amplicon sequencing protocol [24].

\section{Results}

\section{Bacterial families and species identified in the remedies}

The findings of this study revealed the presence of both pathogenic and non-pathogenic bacteria in the polyherbal medicines used for the treatment of tuberculosis in the Eastern Cape Province of South Africa. All the identified bacteria in the therapies belong to 12 families. Only one of the families could not be identified (Fig. 2). However, the prevalent families in all the polyherbal medicines are the Enterobacteriaceae, Bacillaceae and Paenibacillaceae (Fig. 2).

While the majority of the bacteria identified in KWTa remedy are Enterobacteriaceae (68\%), others were Bacillaceae (23\%), with $9 \%$ remaining unknown (Fig. 3a). In the same vein, Enterobacteriaceae are the dominant organisms in KWTb remedy and only $8 \%$ remaining unknown (Fig. 3b). The family Bacillaceae dominate KWTc therapy (66\%), whereas only $3 \%$ of the bacteria are unknown (Fig. 3c). The identities of the majority of bacteria present in the herbal medicines sourced from AL and EL were unknown ( 84 and $86 \%$, respectively), with the remaining bacteria belonging to 16 and 5 families in $\mathrm{AL}$ and EL samples, respectively (Figs. 3d, e). A high number of bacteria identified in FB belong to Paenibacillaceae (98\%) as against a few other remedies where their population is insignificant (Fig. 3f). Similarly, HBfs, HBss and HBts remedies were dominated by Enterobacteriaceae (Figs. 3g-i).

This study further investigated the bacterial species present in each of the polyherbal medicines. The overall blast output revealed that these polyherbal remedies are contaminated with different bacterial genera and species including Bacillus sp., Klebsiella sp., Rahnella sp., Paenibacillus sp., Enterobacter sp., Pantoea sp., Clostridium sp., and a few unknown (Table 1). Some of these bacteria that are clinically pathogenic to human include Raoultella ornithinolytica, Rahnella aquatilis, 


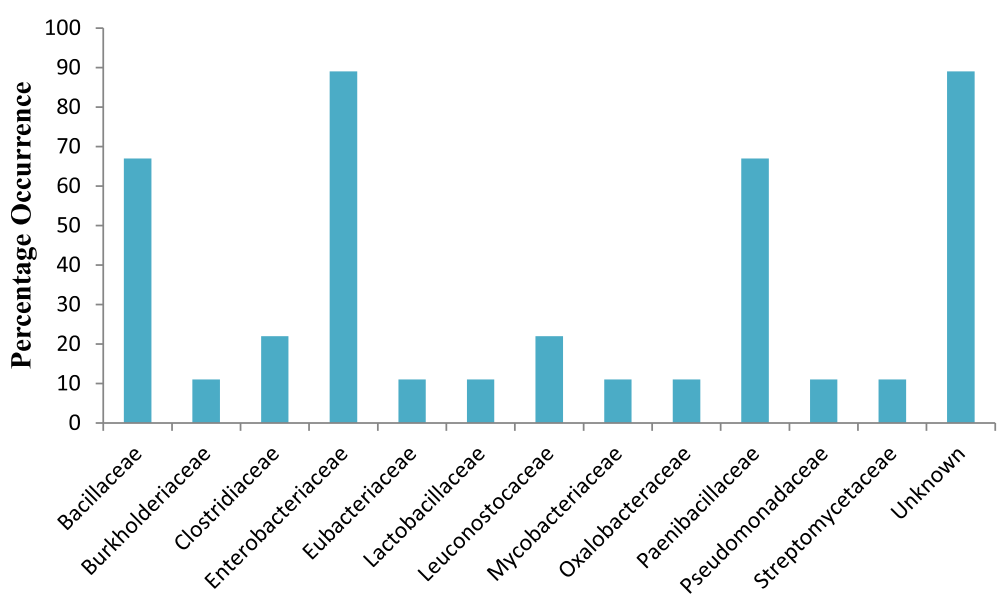

Total Bacterial Families

Fig. 2 Percentage occurrence of each bacteria family identified in all the polyherbal remedy

Bacillus anthracis, Bacillus cereus, Salmonella enteric, Enterobacter cloacae, Klebsiella oxytoca and Klebsiella pneumonia. Others such as Enterobacter asburiae, Paenibacillus polymyxa, Pantoea rwandensis, Klebsiella variicola and Pseudomonas sp. are opportunistic pathogens causing opportunistic infections in individuals with impaired immunity.

\section{Discussion}

The use of polyherbal medicines for the treatment of various diseases is still a significant practice in the developing countries including South Africa. With the popularity and global market expansion, the safety of herbal products has become a major concern to public health [25]. In this study, all the polyherbal therapies used for the treatment of tuberculosis are orally consumed in the form of water-extracted remedies. Naturally, the ingredients used for the preparation of these remedies are not usually sterilized before soaking in water, hence the presence of different bacteria species and families identified in the polyherbal medicines. The main source of contamination could be from the soil, water, plant or other raw materials and the containers used. Since these remedies are not prepared in a sterile manner, another possible source of contamination could be contaminants from the personnel(s), unhygienic production conditions, during harvesting, drying and storage. In addition, environmental factors such as temperature, humidity and extent of rainfall during pre-harvesting and postharvesting periods can influence the microbial contamination of these medicinal herbal [26].

The presence of Bacillaceae, such as B. cereus and $B$. anthracis, and Enterobacteriaceae including $R$. ornithinolytica, Rahnella sp., Klebsiella sp. and Enterobacter sp. in these polyherbal medicines is a cause for concern.
Some of these bacteria are pathogenic to humans while others are opportunistic pathogens (Table 1) but could be serious public health hazard causing opportunistic infection and reduces the immunity of the immunesuppressed consumers. $R$. ornithinolytica (formerly named Klebsiella ornithinolytica) was identified in KWTa remedy. This bacterium is Gram-negative, non-motile, encapsulated and aerobic bacillus [27]. Though an uncommon human pathogen, about 86 infectious cases of this organism have been reported [28]. This pathogen has been linked to bacteremia [29, 30], sepsis [31], acute suppuration of the pancreatic duct [32], soft tissue infection [33], enteric fever [34], renal cysts [35] and urinary tract infection [36]. Also, it expresses chromosomal class A $\beta$-lactamases, which confer resistance to ampicillin and other aminopenicillins [28].

R. aquatilis was identified in AL remedy, KWTa, KWTb and KWTc remedies (Table 1). The bacterium is a facultatively anaerobic, nitrogen-fixing and Gram-negative rodshaped organism. It has been reported to cause infections such as bacteremia, sepsis, respiratory infection, urinary tract infection and wound infections most especially in immune-suppressed individuals [37, 38]. Also, about 18 cases of human infection caused by $R$. aquatilis has been reported, and majority of these infections were accompanied by diabetes mellitus, alcoholism, cancer and AIDS [38]. The presence of this bacterium in the polyherbal remedies is a cause for concern considering the immunocompromised status of the patients.

Bacillus species such as Bacillus cereus, B. anthracis and B. subtilis were also identified in the polyherbal remedies. Bacillus cereus is a Gram-positive, aerobic-tofacultative, spore-forming rod bacterium bearing close phenotypic and genetic relationships to several Bacillus species most especially B. anthracis [39]. This bacterium 
a

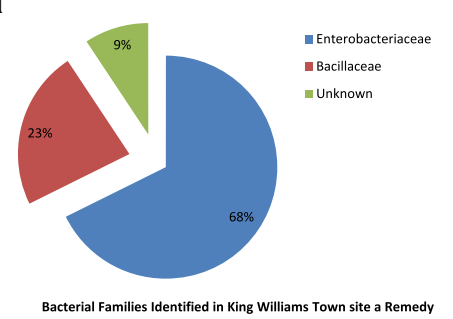

C

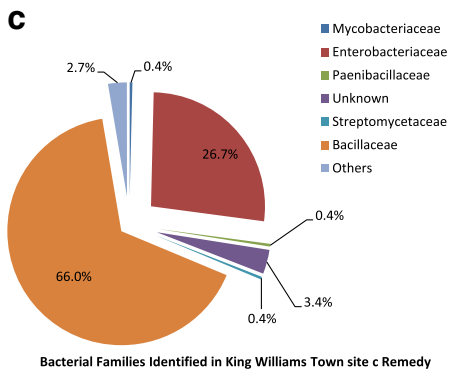

e

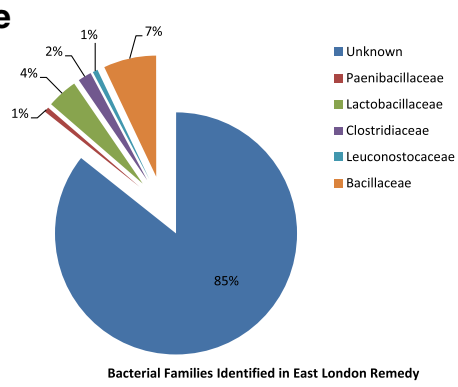

g

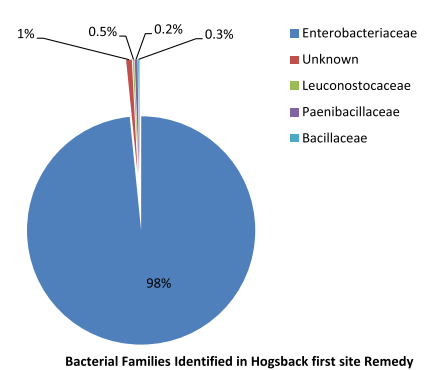

b

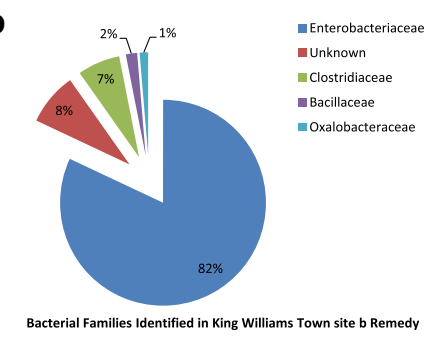

d

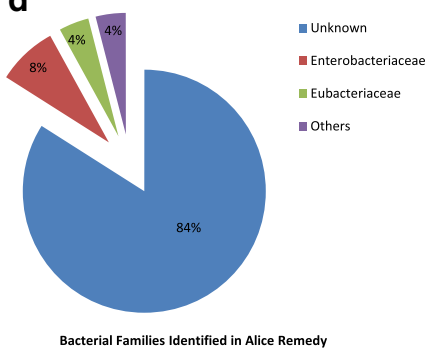

$\mathbf{f}$

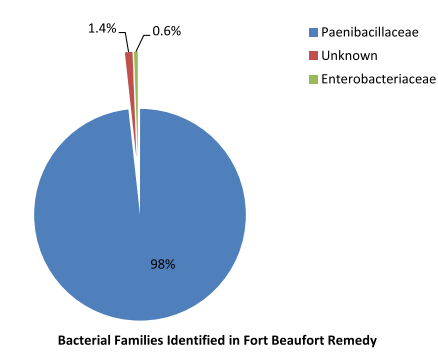

h

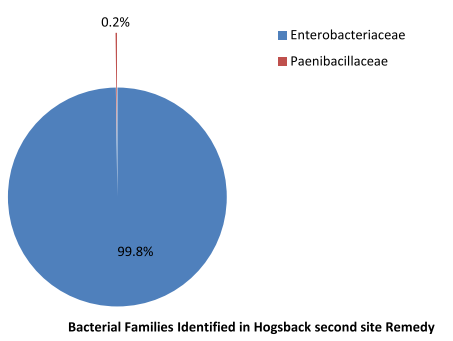

i

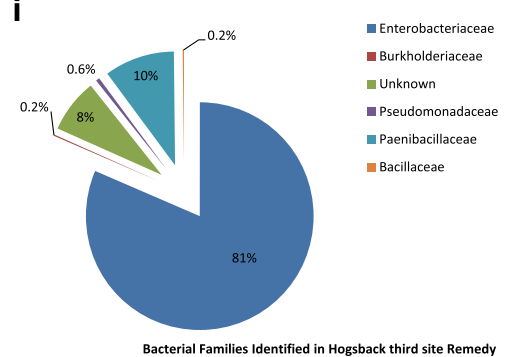

Fig. 3 Relative frequencies of contaminating organisms in each polyherbal remedy 
Table 1 Pathogenic and non-pathogenic bacterial species identified metagenomically from the polyherbal medicines used for the treatment of tuberculosis in the Eastern Cape Province of South Africa

\begin{tabular}{|c|c|c|c|c|c|c|c|c|}
\hline KWTa & KWTb & KWTC & $\mathrm{AL}$ & EL & $F B$ & HBfs & HBss & HBts \\
\hline $\begin{array}{l}\text { *a Raoultella } \\
\text { ornithinolytica }\end{array}$ & ${ }^{* a}$ Rahnella aquatilis & $\begin{array}{l}{ }^{\mathrm{nb}} \text { Bacillus } \\
\text { thuringiensis }\end{array}$ & ${ }^{* a}$ Rahnella aquatilis & ${ }^{* \mathrm{~b}}$ Bacillus cereus & ${ }^{\mathrm{h}}$ Paenibacillus sp. & ${ }^{\mathrm{a}}$ Enterobacter sp. & ${ }^{* a}$ Klebsiella oxytoca & ${ }^{\mathrm{nb}}$ Bacillus subtilis \\
\hline${ }^{* b}$ Bacillus anthracis & 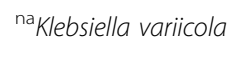 & *a Rahnella aquatilis & $\begin{array}{l}\text { njEubacterium } \\
\text { moniliforme }\end{array}$ & $\begin{array}{l}{ }^{\mathrm{nb}} \text { Lysinibacillus } \\
\text { sphaericus }\end{array}$ & ${ }^{\text {nh }}$ Paenibacillus terrae & hPaenibacillus sp. & ${ }^{\mathrm{a}}$ Enterobacter sp. & $\begin{array}{l}\text { nhPaenibacillus } \\
\text { polymyxa }\end{array}$ \\
\hline *bacillus cereus & ${ }^{* a}$ Klebsiella oxytoca & ${ }^{\mathrm{b}}$ Bacillus sp. & $\begin{array}{l}\text { Uncultured } \\
\text { firmicutes }\end{array}$ & ${ }^{\mathrm{nk}}$ Lactobacillus sp. & ${ }^{\mathrm{a}}$ Enterobacter sp. & $\begin{array}{l}\text { napectobacterium } \\
\text { carotovorum }\end{array}$ & $\begin{array}{l}\text { aUncultured } \\
\text { enterobacter }\end{array}$ & $\begin{array}{l}\text { napantoea } \\
\text { rwandensis }\end{array}$ \\
\hline $\begin{array}{l}\text { *a Klebsiella } \\
\text { pneumoniae }\end{array}$ & ${ }^{* b}$ Bacillus cereus & ${ }^{* b}$ Bacillus cereus & $\begin{array}{l}\text { Uncultured } \\
\text { bacterium }\end{array}$ & $\begin{array}{l}{ }^{\text {ne } C l o s t r i d i u m ~} \\
\text { thiosulfatireducens }\end{array}$ & $\begin{array}{l}\text { Uncultured } \\
\text { bacterium }\end{array}$ & ${ }^{\mathrm{b}}$ Bacillus sp. & $\begin{array}{l}\text { na Enterobacter } \\
\text { cloacae }\end{array}$ & $\begin{array}{l}\text { na Pantoea } \\
\text { agglomerans }\end{array}$ \\
\hline *a Rahnella aquatilis & $\begin{array}{l}{ }^{* a} \text { Klebsiella } \\
\text { pneumoniae }\end{array}$ & $\begin{array}{l}\text { Uncultured } \\
\text { bacterium }\end{array}$ & - & 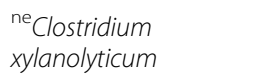 & $\begin{array}{l}\text { Uncultured } \\
\text { actinobacterium }\end{array}$ & 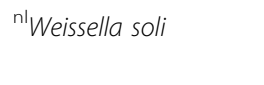 & $\begin{array}{l}\text { nhPaenibacillus } \\
\text { polymyxa }\end{array}$ & $\begin{array}{l}{ }^{* a} \text { Klebsiella } \\
\text { pneumoniae }\end{array}$ \\
\hline aEnterobacter sp. & $\begin{array}{l}{ }^{* a} \text { Salmonella } \\
\text { enterica }\end{array}$ & ${ }^{n}$ Kluyvera intermedia & - & hPaenibacillus sp. & - & Uncultured firmicutes & $\begin{array}{l}{ }^{\text {na }} \text { Citrobacter } \\
\text { freundii }\end{array}$ & $\begin{array}{l}{ }^{\mathrm{nm}} \text { Burkholderia } \\
\text { xenovorans }\end{array}$ \\
\hline 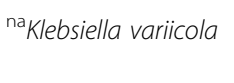 & $\begin{array}{l}{ }^{\mathrm{nf}} \text { Herbaspirillum } \\
\text { frisingense }\end{array}$ & $\begin{array}{l}{ }^{\mathrm{ng}} \text { Mycobacterium } \\
\text { chelonae }\end{array}$ & - & $\begin{array}{l}\text { eUncultured } \\
\text { clostridium }\end{array}$ & - & Uncultured bacterium & - & ${ }^{\mathrm{np}}$ Pseudomonas sp. \\
\hline nateclercia sp. & $\begin{array}{l}\text { naEnterobacter } \\
\text { cloacae }\end{array}$ & ${ }^{\mathrm{nh}}$ Paenibacillus sp. & - & ${ }^{\mathrm{n}}$ Weissella soli & - & - & - & ${ }^{\text {na }}$ Pantoea vagans \\
\hline $\begin{array}{l}\text { buncultured } \\
\text { bacillus }\end{array}$ & $\begin{array}{l}\text { naEnterobacter } \\
\text { asburiae }\end{array}$ & $\begin{array}{l}\text { nistreptomyces } \\
\text { leeuwenhoekii }\end{array}$ & - & Uncultured bacterium & - & - & - & ${ }^{a}$ Klebsiella sp. \\
\hline 'Bacterium nxked5 & $\begin{array}{l}\text { eUncultured } \\
\text { clostridium }\end{array}$ & - & - & $\begin{array}{l}{ }^{\mathrm{nl}} \text { Leuconostoc } \\
\text { mesenteroides }\end{array}$ & - & - & - & a Pantoea sp. \\
\hline $\begin{array}{l}{ }^{\mathrm{nb}} \text { Bacillus } \\
\text { thuringiensis }\end{array}$ & 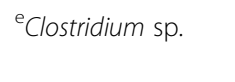 & - & - & buncultured bacilli & - & - & - & $\begin{array}{l}\text { Uncultured } \\
\text { bacterium }\end{array}$ \\
\hline $\begin{array}{l}\text { Uncultured } \\
\text { bacterium }\end{array}$ & ${ }^{{ }^{\circ} B a c t e r i u m ~ m j 07}$ & - & - & - & - & - & - & - \\
\hline- & $\begin{array}{l}\text { naKosakonia } \\
\text { radicincitans }\end{array}$ & - & - & - & - & - & - & - \\
\hline- & ${ }^{\mathrm{C} B a c t e r i u m ~ m j 15}$ & - & - & - & - & - & - & - \\
\hline- & ${ }^{c}$ Bacterium bx4 & - & - & - & - & - & - & - \\
\hline- & $\begin{array}{l}\text { Uncultured } \\
\text { bacterium }\end{array}$ & - & - & - & - & - & - & - \\
\hline
\end{tabular}

Polyherbal medicines were collected from the following: KWTa King Williamstown site A, KWTb King Williamstown site B, KWTC King Williamstown site C, AL Alice, EL East London, FB Fort Beaufort, HBft Hogsback first treatment, HBst Hogsback second treatment, HBtt Hogsback third treatment

- absent, *pathogenic to human, $a$ Enterobacteriaceae, $b$ Bacilliaceae, $n$ non-pathogenic, $c$ unclassified bacteria, $e$ Clostridiaceae, $f$ Oxalobacteraceae, $g$ Mycobacteriaceae, $h$ Paenibacillaceae, $i$ Streptomycetaceae,

$j$ Eubacteriaceae, $k$ Lactobacillaceae, $I$ Leuconostocaceae, $m$ Burkholderiaceae, $p$ Pseudomonadaceae 
is an emerging human food-borne pathogen. B. cereus has been reported to be associated with severe local and systemic human infections such as endophthalmitis, pneumonia, lung infections, bloody diarrhoea, gastroenteritis and meningitis, posing a serious public health problem $[40,41]$. The pathogenicity of $B$. cereus depends on its ability to colonise, persist and subsequently invade the host tissues [42]. The ability of this bacterium to produce emetic toxins has been also associated with gastro- and non-gastrointestinal infections [43].

B. anthracis is an obligate pathogen that infects many vertebrates. It is the causative agent of anthrax. Anthrax is an infectious disease that can infect humans in three different ways, namely cutaneous anthrax, inhalation anthrax and gastrointestinal anthrax [44]. The presence of this bacterium in the remedies could be due to the availability of its endospores in the soil where the herb ingredients are harvested. The presence of Bacillus sp. in these remedies poses great risks to the consumers.

Klebsiella species are Gram-negative, non-motile and usually encapsulated rod-shaped bacteria [45]. Species of this genus have been increasingly associated with hospital infections [46]. They are common pathogens of nosocomial pneumonia, septicaemia, urinary tract infection, wound infections, intensive care unit infections and neonatal septicaemias [45]. K. pneumoniae, $K$. oxytoca and $K$. variicola were detected in the remedies. $K$. pneumoniae is the most pathogenic to humans. Infections with this bacterium are usually hospitalacquired. These include urinary tract infection, pneumonia, intra-abdominal infection, bloodstream infection, meningitis and pyogenic liver abscess [47]. K. pneumoniae has been reported to posses several intrinsic and acquired mechanisms which make it resistant to several antimicrobial agents $[48,49]$.

S. enterica was identified in KWTb remedy. It is a rodshaped, Gram-negative, flagellated facultative anaerobe. The bacterium is a medically important pathogen of both humans and animals. The presence of this bacterium in this remedy is of concern because $S$. enterica is known to cause diseases such as gastroenteritis, septicaemia and enteric fever clinically [50]. Like many other infectious diseases, the infection severity of Salmonella may vary depending on the resistance of individual to the pathogen, the immune system and the virulence strain [50].

Enterobacter species are rod-shaped, non-spore-forming, facultative anaerobes and Gram-negative bacilli bacteria. Several strains of these bacteria are increasingly been identified as nosocomial pathogens causing infections in hosts with impaired immunity [51]. They have been reported to cause $5 \%$ of hospital-acquired septicemias, $5 \%$ of nosocomial pneumonias, $4 \%$ of nosocomial urinary tract infections and $10 \%$ of postsurgical peritonitis cases [52]. Skin and soft tissue infection, endocarditis, intra-abdominal infection, septic arthritis, osteomyelitis and ophthalmic infection have been associated with these bacteria. E. cloacae is ubiquitous in nature, although generally not known to be an enteric pathogen; it is an opportunistic pathogen in humans $[53,54]$. A wide spectrum of infections such as the urinary tract, lower respiratory tract, skin and soft tissue, biliary tract, wounds, intravenous catheters and the central nervous system have been associated with Enterobacter cloacae [55].

None of the analysed marketed polyherbal remedies had any form of food-based tests carried out on them since they are locally made medicines. This may probably account for the high discovery of bacterial population in the remedies. The results from different findings conducted on microbial quality of traditional herbal medicines have been alarming revealing the presence of pathogenic bacteria and other contaminants in the herbal therapies [13-15, 17, 56]. Several fatal infectious outbreaks have been associated with the use of heavily contaminated raw materials of natural origin with pathogens; thus, great efforts are necessary to guarantee constant and adequate quality [57].

The prevalence of the members of Enterobacteriaceae in all the herbal remedies was recorded (Fig. 2). Enterobacteria are found in nature and are often thought as indicating faecal contamination. Thus, their presence could be regarded as an index of the degree of contamination, which may indicate possible presence of harmful or disease causing organisms [58-60]. Also, higher numbers of spore-forming bacteria such as Bacillus sp. and a few numbers of Clostridium sp. found in the remedies could be due to the fact that some of these organisms produce spores which are resistant to harsh processing, elevated heat and dry conditions, thereby able to survive for a very long time on the products in dormant states [26]. Likewise, the members of Paenibacillaceae which are Gram-positive and are aerobic bacteria that are related to Bacilli were found in the remedies. Until recently, these organisms were not known to cause human disease, but now, there are several reports of human infections caused by some members of this genus [61].

\section{Conclusions}

The findings of this study revealed different bacteria populations in the polyherbal medicines used for the treatment of tuberculosis in the Eastern Cape Province of South Africa; this is a cause for concern. Since there are no legislative criteria governing the microbial quality of these therapies in South Africa, there is an urgent need for the Government to take adequate control measures to set specific standards for quality of these medicines, considering the fact that these medicines are being taking by immunocompromised individuals. Also, there is 
a need to educate the public as well as the traditional healers in the Province, that proper hygienic condition should be maintained in all preparation processes starting from plant collection, processing, packaging and storage, as well as emphasizing on the implications of non-compliance to hygienic conditions to both the consumers and the traditional healers.

\section{Acknowledgements}

The work was supported by National Research Foundation and Medical Research Council both of South Africa. The authors also acknowledge the traditional healers for selling the polyherbal remedies to us.

\section{Funding}

The study was supported by the National Research Foundation and Medical Research Council both of South Africa.

\section{Authors' contributions}

EB carried out the laboratory work and drafted the manuscript. AM participated in the coordination and assisted in the drafting of the manuscript. AJ conceived the study, participated in its design and coordination and revised the manuscript for intellectual content. All authors read and approved the final manuscript

\section{Competing interests}

The authors declare that they have no competing interests.

\section{Consent for publication}

Not applicable.

\section{Ethics approval and consent to participate}

Not applicable.

\section{Received: 26 February 2016 Accepted: 8 August 2016}

Published online: 22 August 2016

\section{References}

1. Louw CAM, Regnier TJC, Korsten L. Medicinal bulbous plants of South Africa and their traditional relevance in the control of infectious diseases. J Ethnopharmacol. 2002;82(2):147-54.

2. Buwa LV, Afolayan AJ. Antimicrobial activity of some medicinal plants used for the treatment of tuberculosis in the Eastern Cape Province, South Africa. Afr J Biotechnol. 2009:8:23

3. Lawal IO, Grierson DS, Afolayan AJ. Phytotherapeutic information on plants used for the treatment of tuberculosis in Eastern Cape Province, South Africa. Evid Based Complement Altern Med. 2014. doi: 10.1155/2014/735423.

4. Kasprowicz VO, Churchyard G, Lawn SD, Squire SB, Lalvani A. Diagnosing latent tuberculosis in high-risk individuals: rising to the challenge in high-burden areas. J Infect Dis. 2011;204(4):1168-78.

5. World Health Organization. Global tuberculosis control: a short update to the 2009 report. Geneva: WHO; 2009.

6. Hanifa Y, Grant AD, Lewis J, Corbett EL, Fielding K, Churchyard G. Prevalence of latent tuberculosis infection among gold miners in South Africa. Int J Tuberculosis Lung Dis. 2009;13(1):39-46.

7. Wood R, Liang H, Wu H, Middelkoop K, Oni T, Rangaka MX, Lawn SD. Changing prevalence of tuberculosis infection with increasing age in high-burden townships in South Africa. Int J Tuberculosis Lung Dis. 2010;14(4):406-12.

8. Loddenkemper R, Hauer B. Drug-resistant tuberculosis: a worldwide epidemic poses a new challenge. Dtsch Arztebl Int. 2010;107(1-2):10.

9. Udwadia ZF, Amale RA, Ajbani KK, Rodrigues C. Totally drug-resistant tuberculosis in India. Clin Infect Dis. 2012;54(4):579-81.

10. Sloan DJ, Davies GR, Khoo SH. Recent advances in tuberculosis: new drugs and treatment regimens. Curr Res Med Rev. 2013;9(3):200.

11. World Health Organization: Treatment of Tuberculosis: Guildlines for National Programmes. Third Edition. WHO Geneva, 2003. (WHO/CDS/TB 2003.313).

12. Orodho JA, Kirimuhuzya C, Otieno JN, Magadula JJ, Okemo P. Local management of tuberculosis by traditional medicine practitioners in Lake Victoria Region. Open Complement Med J. 2011;3:1-9.

13. Alwakeel S. Microbial and heavy metals contamination of herbal medicines. Res J Microbiol. 2008;3(12):683-91.
14. Kaume L, Foote JC, Gbur EE. Microbial contamination of herbs marketed to HIV-infected people in Nairobi (Kenya). South Afr J Sci. 2012;108(9-10):1-4

15. Ting A, Chow Y, Tan W. Microbial and heavy metal contamination in commonly consumed traditional Chinese herbal medicines. J Tradit Chin Med. 2013;33(1):119-24

16. Noor R, Huda N, Rahman F, Bashar T, Munshi SK. Microbial contamination in herbal medicines available in Bangladesh. Bangladesh Med Res Counc Bull. 2014;39(3):124-9.

17. Adeleye IA, Okogi G, Ojo EO. Microbial contamination of herbal preparations in Lagos, Nigeria. J Health Popul Nutr. 2011;23(3):296-7.

18. Govender S, Du Plessis-Stoman D, Downing TG, Van de Venter M. Traditional herbal medicines: microbial contamination, consumer safety and the need for standards: research letter. South Afr J Sci. 2006:102(5 \& 6):253.

19. Candlish AAG, Pearson SM, Aidoo KE, Smith JE, Kelly B, Irvine H. A survey of ethnic foods for microbial quality and content aflatoxin. Food Addit Contam. 2001;18(2):129-36.

20. Kneifel W, Czech E, Kopp B. Microbial contamination of medicinal plants-a review. Planta Med. 2002;68(1):5-15.

21. Dei-Tutuwa D, Amuna P, Rahman MA. Rapid detection of microbial contamination in Ghanaian herbal medicines by PCR analysis. Ghana Med J. 2014:48(2):106-11.

22. Baker GC, Smith JJ, Cowan DA. Review and re-analysis of domain-specific $16 S$ primers. J Microbiol Methods. 2003:55(3):541-55.

23. Zhang S, Hou S, Ma X, Qin D, Chen T. Culturable bacteria in Himalayan glacial ice in response to atmospheric circulation. Biogeosciences. 2007:4:1-9.

24. Kozich JJ, Westcott SL, Baxter NT, Highlander SK, Schloss PD. Development of a dual-index sequencing strategy and curation pipeline for analyzing amplicon sequence data on the MiSeq Illumina sequencing platform. Appl Environ Microbiol. 2013;79(17):5112-20.

25. World Health Organization. Guidelines for assessing quality of herbal medicines with reference to contaminants and residue. Geneva: WHO; 2007.

26. De Freitas Araujo MG, Bauab TM. Microbial quality of medicinal plant materials. 2012. doi: $10.5772 / 51072$

27. Walckenaer E, Poirel L, Leflon-Guibout V et al. Genetic and biochemical characterization of the chromosomal class A $\beta$-lactamases of Raoultella (formerly Klebsiella) planticola and Raoutella ornithinolytica. Antimicrob Agents Chemother. 2004;48(1):305-12.

28. Seng P, Boushab BM, Romain F, Gouriet F, Bruder N, Martin C, Papazian L. Emerging role of Raoultella ornithinolytica in human infections: a series of cases and review of the literature. Int J Infect Dis. 2016:45:65-71.

29. Hadano Y, Tsukahara M, Ito K, Suzuki J, Kawamura I, Kurai H. Roultella ornithinolytica bacteremia in cancer patients: report of three cases. Int Med. 2012:51(22):3193-5.

30. Nakasone ES, Kaneshiro R, Min K, Tokeshi J. Emergence of Raoultella ornithinolytica on $O$ 'ahu: a case of community-acquired $R$. ornithinolytica urinary tract infection. Hawai'i J Med Public Health. 2015;74(5):174

31. Sandal G, Ozen M. Fatal Raoultella ornithinolytica sepsis and purpura fulminans in a preterm newborn. Indian J Paediatr Dermatol. 2014;15(1):24-6.

32. Deeb LS, Bajaj J, Bhargava S, Alcid D, Pitchumoni CS. Acute suppuration of the pancreatic duct in a patient with tropical pancreatitis. Case Rep Gastroenterol. 2008:2(1):27-32.

33. Solak Y, Gul EE, Atalay H, Genc N, Tonbul HZ. A rare human infection of Raoultella ornithinolytica in a diabetic foot lesion. Ann Saudi Med. 2011:31(1):93-4.

34. Morais VP, Daporta MT, Bao AF, Campello MG, Andrés GQ. Enteric fever-like syndrome caused by Raoultella ornithinolytica (Klebsiella ornithinolytica). J Clin Microbiol. 2009:47(3):868-9.

35. Vos B, Laureys M. Giant renal cyst as cause of colic obstruction. Rev Med Brux. 2009;30(2):107-9.

36. Lehloenya R, Christians S. A case of chronic urticaria complicated by Raoultella ornithi nolytica urinary tract infection, bronchospasm, and angioedema. World Allergy Organ J. 2012;5(2):204

37. Caroff N, Chamoux C, Le Gallou F, Espaze E, Gavini F, Gautreau D, Reynaud A. Two epidemiologically related cases of Rahnella aquatilis bacteremia. European J Clin Microbiol Infect Dis. 1998:17(5):349-52.

38. Kuzdan C, Soysal A, Özdemir H, Coşkun Ş, Akman I, Bilgen H, Bakır M. Rahnella aquatilis sepsis in a premature newborn. Case Rep Paediatr. 2015.

39. Ash C, Farrow JA, Dorsch M, Stackenbrandt E, Collins MD. Comparative analysis of Bacillus anthracis, Bacillus cereus, and related species on the basis of reverse transcriptase of 16S rRNA. Int J Syst Bacteriol. 1991;41:343-6.

40. Bottone EJ. Bacillus cereus, a volatile human pathogen. Clin Microbiol Rev. 2010;23:382-98 
41. Hilliard NJ, Schelonka RL, Waites KB. Bacillus cereus bacteremia in a preterm neonate. J Clin Microbiol. 2003;41:3441-4.

42. Kamar R, Gohar M, Jéhanno I, Réjasse A, Kallassy M, Lereclus D, Ramarao N. Pathogenic potential of Bacillus cereus strains as revealed by phenotypic analysis. J Clin Microbiol. 2013;51(1):320-3.

43. Kotiranta A, Lounatmaa K, Haapasalo M. Epidemiology and pathogenesis of Bacillus cereus infections. Microbes Infect. 2000;2(2):189-98.

44. Lerner BW, Lee Lerner K, editors. Anthrax infectious diseases: in context. 2008. p. 41-7.

45. Janda JM, Abbott SL. The genera Klebsiella and Raoultella. The Enterobacteria. 2nd ed. Washington: ASM Press; 2006. p. 115-29.

46. Rosenblueth M, Martinez L, Silva J, Martinez-Romero E. Klebsiella variicola, a novel species with clinical and plant-associated isolates. Syst Appl Microbiol. 2004;27(1):27-35.

47. Maatallah M, Vading M, Kabir MH, Bakhrouf A, Kalin M, Nauclér P, Giske CG. Klebsiella variicola is a frequent cause of bloodstream infection in the Stockholm area, and associated with higher mortality compared to K. pneumoniae. PLoS One. 2014;9(11):113539

48. Donnarumma F, Indorato C, Mastromei G, Goti E, Nicoletti P, et al. Molecular analysis of population structure and antibiotic resistance of Klebsiella isolates from a three-year surveillance program in Florence hospitals, Italy. Eur I Clin Microbiol Infect Dis. 2011;31:371-8.

49. Yusuf I, Arzai AH, Umah A, Magaji N, Salisu N, Tukur A, Hamid KM. Prevalence of extended spectrum beta lactamases (ESBL) producing Escherichia coli and Klebsiella pneumoniae in tuberculosis patients in Kano, Nigeria. Bayero J Pure Applied Sci. 2011:4(2):182-5.

50. Andino A, Hanning I. Salmonella enterica: survival, colonization, and virulence differences among serovars. Sci World J. 2015.

51. Blot SI, Vandewoude KH, Colardyn FA. Evaluation of outcome in critically ill patients with nosocomial enterobacter bacteremia: results of a matched cohort study. Chest J. 2003;123(4):1208-13.

52. Hoffmann $H$, Roggenkamp A. Population genetics of the nomenspecies Enterobacter cloacae. Appl Environ Microbiol. 2003;69(9):5306-18.

53. Nishijima KA, Wall MM, Siderhurst MS. Demonstrating pathogenicity of Enterobacter cloacae on macadamia and identifying associated volatiles of gray kernel of macadamia in Hawaii. Plant Dis. 2007;91(10):1221-8.

54. Mezzatesta ML, Gona F, Stefani S. Enterobacter cloacae complex: clinical impact and emerging antibiotic resistance. Future Microbiol. 2012;7(7):887-902.

55. Lee CC, Lee NY, Yan JJ, Lee HC, Chen PL, Chang CM, Ko WC. Bacteremia due to extended-spectrum- $\beta$-lactamase-producing Enterobacter cloacae: role of carbapenem therapy. Antimicrobial Agents Chemother. 2010;54(9):3551-6.

56. Osei-Adjei G, Hackman HK, Mills-Robertson FC, Tay SCK. Quality assessment of aqueous herbal/medicinal products sold on the Ghanaian market. Food Sci Qual Manage. 2013;20:13-8.

57. Baur R. Quality criteria and standardization of phytopharmaceuticals: can acceptable drugs standard be achieved? Drugs Inf J. 1998;32:101-10.

58. American Public Health Association (APHA). Standard methods for the examination of water and wastewater. 18th ed. Washington D.C: American Public Health Association; 1992. p. 9-66. Table 9225: I.

59. Pelczar Jr MJ, Chan EC, Nee R. A textbook of microbiology. International edition. 1993.

60. Jay JM. Modern food microbiology. Fifth Edition. Aspen Publishers, Inc, Maryland. 2012;633. doi:10.1007/978-1-4615-7476-7.

61. Ouyang J, Pei Z, Lutwick L, Dalal S, Yang L, Cassai N, Pincus MR. Paenibacillus thiaminolyticus: a new cause of human infection, inducing bacteremia in a patient on hemodialysis. Ann Clin Lab Sci. 2008;38(4):393-400.

\section{Submit your next manuscript to BioMed Central and we will help you at every step:}

- We accept pre-submission inquiries

- Our selector tool helps you to find the most relevant journal

- We provide round the clock customer support

- Convenient online submission

- Thorough peer review

- Inclusion in PubMed and all major indexing services

- Maximum visibility for your research

Submit your manuscript at www.biomedcentral.com/submit

C Biomed Central 